\title{
Creating Culture Organizational Citizenship Behavior and Performance Through Human Research Optimization
}

\author{
Syamsul Alam', Yana Fajriah², Muhammad Irwan Nur Hamiddin ${ }^{3}$, Edy Jumady ${ }^{4}$ \\ 1,2,3,4 STIEM Bongaya Makasar \\ Email Addres: \\ syamsul.alam@stiem-bongaya.ac.id
}

\begin{abstract}
We conducted this study to examine and explore the effect of developing human resources, competence, and motivation on Organizational Citizenship Behavior (OCB) and the Performance of State Civil Apparatus. This study uses a quantitative approach involving 320 respondents. Our research data was collected by distributing questionnaires directly to respondents. The results of this study indicate that the development of human resources has a positive and significant effect on Organizational Citizenship Behavior. Competence has a positive and significant effect on Organizational Citizenship Behavior. Positive and significant motivation on Organizational Citizenship Behavior. HR development has a positive and significant impact on the performance of ASN. Competence has a positive and insignificant effect on ASN performance. Positive motivation and not significant to the performance of ASN. Positive and significant motivation on the performance of ASN.
\end{abstract}

Keywords: HR development, competence, motivation, Organizational Citizenship Behavior, performance.

Abstrak: We conducted this study to examine and explore the effect of developing human resources, competence, and motivation on Organizational Citizenship Behavior (OCB) and the Performance of State Civil Apparatus. This study uses a quantitative approach involving 320 respondents. Our research data was collected by distributing questionnaires directly to respondents. The results of this study indicate that the development of human resources has a positive and significant effect on Organizational Citizenship Behavior. Competence has a positive and significant effect on Organizational Citizenship Behavior. Positive and significant motivation on Organizational Citizenship Behavior. HR development has a positive and significant impact on the performance of ASN. Competence has a positive and insignificant effect on ASN performance. Positive motivation and not significant to the performance of ASN. Positive and significant motivation on the performance of ASN.

Keywords: HR development, competence, motivation, Organizational Citizenship Behavior, performance.

\section{INTRODUCTION}

The flow of globalization requires all parties, both individually and in groups, to continue to compete. In the development of globalization, the government demands that employees from the central to the regional levels continue to improve their abilities to 
provide good services for the community. Government services require people who are able and willing to carry out their duties and responsibilities to participate in development and community activities efficiently and effectively.

The performance of the bureaucracy is currently a strategic issue because it has a broad impact in terms of economy and politics (Boyle and Dwyer, 1995). In terms of the economy, improving the performance of the bureaucracy will be able to improve the financial condition that the Indonesian people urgently need in order to get out of the prolonged economic crisis, while in terms of politics, improving the performance of the service bureaucracy will have a broad impact, especially in the level of public trust in the government. The spirit of reform has encouraged the State Civil Apparatus (ASN) to reform and improve the state government system in development, protection, and public services to encourage the community's needs and interests. Good governance in public administration and accountability for the performance of government agencies is a form of government responsibility to the demands and aspirations of the people in achieving the demands of the nation and state.

We carried out this study in Sinjai Regency in the province of South Sulawesi. The results of our initial observations at the research location show that we see that the quantity of ASN is relatively tiny, ASN is still less focused on carrying out their duties because of placements that are not by the capabilities they have, slow to carry out their duties due to inadequate abilities, ASN has not been able to adopt technology in the COVID-19 pandemic situation which requires ASN to carry out work from home. It illustrates that there is a problem related to the performance of ASN because they have not been able to show the best abilities they have, so that it has an impact on increasing OCB and ASN performance.

This study deals with creating a culture of organizational citizenship behavior and optimal performance for state civil servants (ASN) through optimizing the functions and roles of Human Resources (HR). We see that the emergence of a new paradigm of bureaucracy now makes the reform of the HR apparatus bureaucracy a priority through the implementation and development of a learning organization system in the State Civil Apparatus development program. In essence, a learning organization is a climate that can encourage and accelerate individuals, groups, or organizations to continue learning and consistently apply the critical thinking process to understand what should be done and why (Abrianto and Srimulyani, 2021). Learning organizations can be seen as an effort to empower individuals and groups to create knowledge, products, and services through innovative networks within the organization and outside the organization. The application of learning organizations is intended for employees to develop their capacity sustainably in realizing organizational optimization.

Human resources in an organization or institution need to be managed professionally to achieve a balance between the needs of employees and the demands and capabilities of the organization (Chiaburu et al., 2015). This balance is the key to a reasonable organization. Organizational development and productivity are highly dependent on the productivity of human resources in the organization. With the development of professional human resource management, it is expected that employees can work productively and provide high performance (Hartog and Winstanley, 2002). The achievement of organizational goals cannot be separated from the role of HR because they have an active role as actors to achieve organizational goals (Mathis and Jackson, 2006). 


\section{THEORITICAL REVIEW}

(Pradhan and Jena, 2017) mentions six criteria that can be used to measure individual employee performance. 1) The quality of the work carried out is close to perfect or meets the expected goals of the work, 2) The quantity produced or the number of activities that can be completed, 3) Timeliness, which is to be able to complete at a predetermined time and maximize the time available for completion other activities, 4) Effectiveness, maximum utilization of existing resources in the organization to increase profits and reduce losses, 5) Independence, namely being able to carry out work without assistance in order to avoid adverse results, 6) Work Commitment, namely work commitment between employees and employees organization and 7) the responsibility of employees to the organization. A study has two objects under study, namely objects that are influential and influenced.

It then connects why competence becomes something that is needed in achieving performance in an organization (De Waal, 2010). Because achieving success requires high competence. Thus, competence is very much needed by ASN. Because the more competencies they have, the more the capabilities of these resources will be considered because their performance will also increase. It is in line with the opinion of Sunarsih, (2018) introduced a theory of competence based on the Window Theory that each individual's competence is observed from four sides in the form of a window, namely: knowledge, skills, attitudes, and work experience. The essence of the Window Theory is a competence that human resources who have skills supported by mature work experience are human resources who have the ability (capability) to be competitive. It is also in line with (Ginanti et al., 2018) which shows that the higher a person's competence, the higher the resulting performance. (Buana and Wirawati, 2018) suggests a significant influence between competence and OCB.

The relationship between competence and performance refers to the opinion of (House and Wigdor, 1967) which emphasizes intrinsic and extrinsic motivation so that it has an impact on employee performance. (Luthan et al., 2017) explains that intrinsic motivation can encourage someone to be more accomplished, while extrinsic motivation will determine a person's behavior in an organization. The results of the study (Nurun and Dip, 2017) indicate that there is a significant influence of motivation on employee performance. The relationship between motivation and Organizational Citizen Behavior (OCB) refers to the opinion of (Pintrich, 2003) who states that the concept of motivation is used to explain the desire to behave, the direction of behavior (choice), the intensity of behavior (sustainable effort) and completion or work performance. Employee behavior will impact organizational citizen behavior (OCB) consistency due to the freedom to make choices to encourage morale. employee work through a reward system Effectiveness and efficiency on performance are part of organizational functions (Organ, 2018). Empirical evidence can be seen that motivation is closely related to OCB according to research conducted by (Mushtaq et al., 2014); (Reza et al., 2018); (Purwanto et al., 2021) whose findings state that motivation is a significant effect on Organizational Citizen Behavior (OCB).

The correlation between organizational citizenship behavior (OCB) according to (Hall et al., 2009) is employee behavior that exceeds the essential role, which is not directly or explicitly recognized by the formal reward system but is based on its performance. It can be said that someone who works voluntarily for work activities that exceed the workload is not given additional rewards, but their performance is the basis for the assessment. Furthermore, 
the behavior desired by the organization can help transform resources, adaptability, and innovation in improving performance. (Turnipseed and Turnipseed, 2013) research related to organizational citizenship behavior (OCB) with performance, including research by (Tai et al., 2012); (Hidayah Tunggal Wiranti, n.d).; and (Nur et al., 2015) which states that organizational citizenship behavior (OCB) affects performance.

It can be said that OCB is a voluntary activity of members of the organization manifested in expressions, attitudes, and actions that are not self-serving or people's attention. (Organ, 2018) noted that OCB was found to be an alternative explanation for performance-based decisions. When employees work harder than before (different roles), then performance will also increase. Previous empirical evidence suggests that OCB significantly impacts managerial performance appraisal decisions (Jo and Joo, 2011; Harwiki, 2013; Morrison, 1994).

In line with the research objectives and the support by several previous researchers in the reference of this study with the concept of the relationship in question, a theoretical and empirical basic conceptual framework can be made, a conceptual framework in a study. The conceptual framework in question is shown in Figure 4:

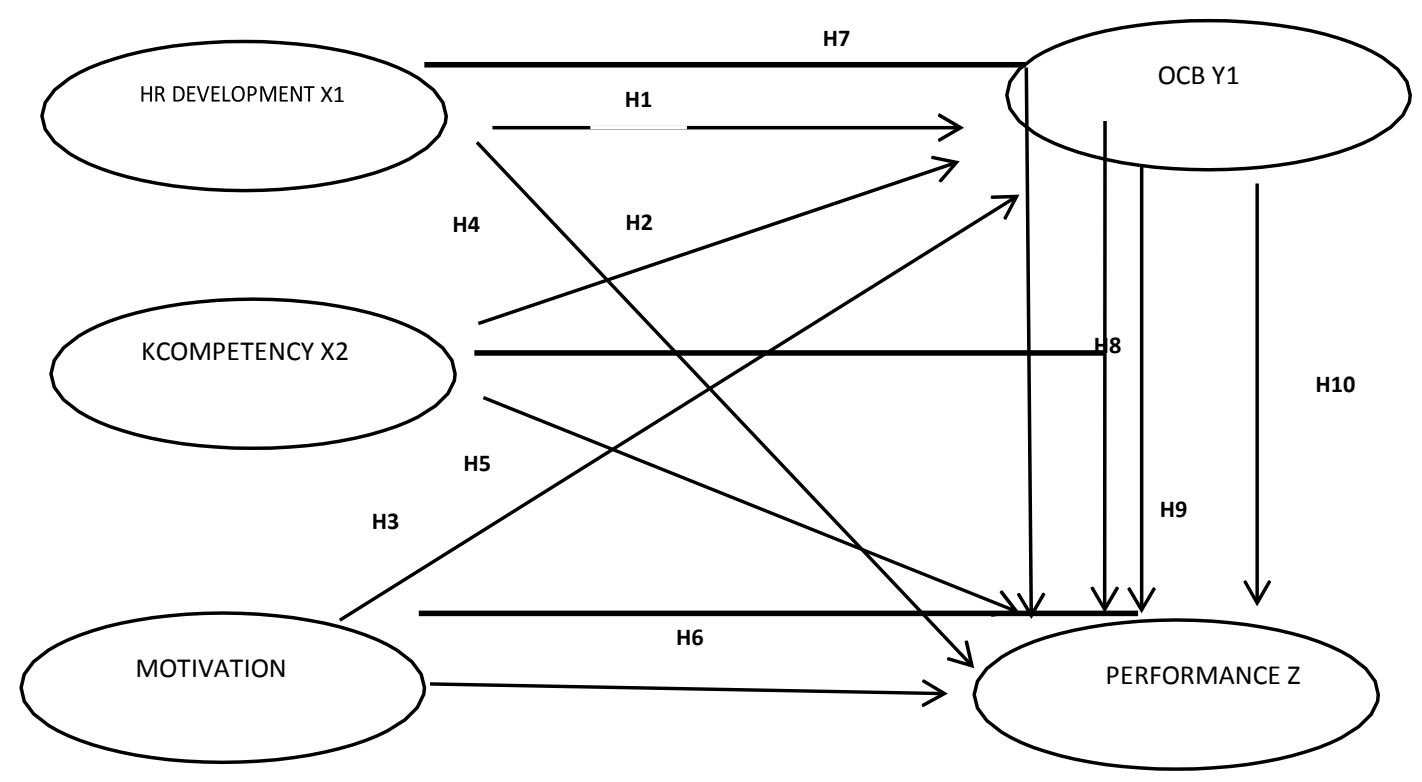

Figure 1. Conceptual framework

H1: Human resource development has a positive and significant effect on OCB ASN Regional Government of Sinjai Regency, South Sulawesi Province.

H2: Competence has a positive and significant effect on OCB of ASN Regional Government of Sinjai Regency, South Sulawesi Province.

H3: Work motivation has a positive and significant effect on OCB of ASN Regional Government of Sinjai Regency, South Sulawesi Province.

H4: Development of ASN has a positive and significant effect on the Performance of ASN Local Government of Sinjai Regency South Sulawesi Province.

H5: Competence has a positive and significant effect on the Performance of ASN Local Government of Sinjai Regency, South Sulawesi Province. 
H6: Work motivation has a positive and significant effect on the Performance of ASN Local Government of Sinjai Regency, South Sulawesi Province.

H7: Human resource development has a positive and significant effect on the performance of ASN in the Sinjai Regency Government of South Sulawesi Province through OCB.

H8: Competence has a positive and significant effect on the Performance of ASN Local Government of Sinjai Regency, South Sulawesi Province through OCB.

H9: Motivation has a positive and significant effect on ASN Performance of the Regional Government of Sinjai Regency, South Sulawesi Province through OCB.

H10: OCB has a positive and significant effect on the performance of the ASN of the Sinjai Regency Government, South Sulawesi Province.

\section{METHODS}

This research was conducted at the Regional Apparatus Organization (OPD) of the Regional Government of Sinjai Regency, South Sulawesi Province. The selection of Regional Apparatus Organizations (OPD) for the Scope of the Regional Government of Sinjai Regency, South Sulawesi Province as the location of this research is based on the reason that researchers see a tendency for high workloads to be carried out or performance that must be carried out with different levels of OCB employees so that it relates to how in human resource development. , Competence possessed by employees and different levels of motivation. The data in our study were collected through the distribution of questionnaires involving 320 respondents consisting of structural State Civil Servants (ASN) of the Sinjai Regency Government, South Sulawesi. The research data will be analyzed with statistical analysis tools using Structural Equation Modeling (SEM).

\section{RESULTS}

The validity test shows the degree of accuracy between the data that occurs on the object and the data collected. The validity of the research instrument was tested by correlating the item scores with the total items. If the coefficient between items with total items is equal to or above 0.3, then the item can be declared valid, and vice versa (Sugiyono, 2016). Therefore, all statements with a correlation level below 0.3 must be corrected because they are considered invalid. A questionnaire is reliable if the respondents' answers to questions are consistent from time to time (Ghozali, 2005). According to (Nunnally et al., 1963) a variable is valid if the Cronbach's Alpha value is $>60 \%$. The results of the validity test can be seen as shown in table 2 .

Table 2. Validity and Reliability Test Results

\begin{tabular}{ccccc}
\hline Variable & Instrument & r-calculated & Cronbach Alpha & Info \\
\hline Organizational & Y1.1 & 0.590 & .580 & Valid \& Reliable \\
Citizenship & Y1.2 & 0.642 & .666 & Valid \& Reliable \\
Behavior. OCB & Y1.3 & 0.603 & .618 & Valid \& Reliable \\
(Y) & Y1.4 & 0.653 & .605 & Valid \& Reliable \\
ASN & Y1.5 & 0.575 & .561 & Valid \& Reliable \\
Performance (Z) & Z1.1 & 0.836 & .609 & Valid \& Reliable \\
& Z1.2 & 0.835 & .611 & Valid \& Reliable \\
\hline
\end{tabular}




\begin{tabular}{ccccc} 
& Z1.3 & 0.702 & .450 & Valid \& Reliable \\
& Z1.4 & 0.715 & .430 & Valid \& Reliable \\
& Z1.5 & 0.705 & .371 & Valid \& Reliable \\
HR Development & X1.1 & 0.692 & .878 & Valid \& Reliable \\
(X1) & X1.2 & 0.610 & .879 & Valid \& Reliable \\
& X1.3 & 0.668 & .885 & Valid \& Reliable \\
Competence & X2.1 & 0.674 & .879 & Valid \& Reliable \\
(X2) & X2.2 & 0.678 & .876 & Valid \& Reliable \\
& X2.3 & 0.771 & .872 & Valid \& Reliable \\
& X2.4 & 0.756 & .873 & Valid \& Reliable \\
& X3.1 & 0.529 & .880 & Valid \& Reliable \\
Motivation (X3) & X3.2 & 0.749 & .875 & Valid \& Reliable \\
& X3.3 & 0.691 & .875 & Valid \& Reliable \\
& X3.4 & 0.814 & .874 & Valid \& Reliable \\
& X3.5 & 0.771 & .873 & Valid \& Reliable \\
\hline
\end{tabular}

As shown in table 2, it can be seen that all variables can be seen that all research indicators have r-count $>$ r-table and are positive, so all instruments are declared valid. All indicators of variables are human resources development, competence, motivation, Organizational Citizenship. The behavior and work of ASN are all reliable, and this can be seen from the value of Cronbach's Alpha if Item Deleted has a value above 0.6. Thus, all research instruments are also declared reliable.

Furthermore, to be able to determine the variables that can be used as indicators of exogenous variables (HR development, competence, and motivation), it can be observed from the regression value and the level of significance ( $\mathrm{p}^{* * *}$ ), meaning the probability value $<0.05$ or 0.000 , which reflects each exogenous variable as an indicator is shown in table 3 .

Table 3. Loading Factor and Critical Ratio Indicator Variable

\begin{tabular}{cccccc}
\hline Variable & Indicator & $\begin{array}{c}\text { Loading Factor } \\
(\boldsymbol{\chi})\end{array}$ & $\begin{array}{c}\text { Crirical } \\
\text { Ratio. }\end{array}$ & $\begin{array}{c}\text { Profitability } \\
(\mathbf{p})\end{array}$ & Info \\
\hline HR Development & X1.1 & 0,558 & FIX & 0,000 & Significant \\
(X1) & X1.2 & 0,444 & 3,984 & 0,000 & Significant \\
& X1.3 & 0,241 & 2,740 & 0,006 & Significant \\
Competence & X2.1 & 0,418 & 6,467 & 0,000 & Significant \\
(X2) & X2.2 & 0,458 & 6,756 & 0,000 & Significant \\
& X2.3 & 0,798 & FIX & 0,000 & Significant \\
& X2.4 & 0,731 & 10,900 & 0,000 & Significant \\
Motivation & X3.1 & 0,326 & 5,311 & 0,000 & Significant \\
(X3) & X3.2 & 0,664 & 10,962 & 0,000 & Significant \\
& X3.3 & 0,594 & 9,635 & 0,000 & Significant \\
& X3.4 & 0,788 & FIX & 0,000 & Significant \\
& X3.5 & 0,746 & 12,219 & 0,000 & Significant \\
\hline
\end{tabular}

Table 4 shows positive and significant values for the three indicators. These results indicate that the test results of the variable measurement model show a significant $p$-value construct so that all indicators can be included in the next test. The results of the 
Confirmatory Factor Analysis (CFA) test for the exogenous variable, namely Organizational Citizenship Behavior (Y), the ASN performance variable produced the following model:

Table 4. Evaluation of Variable Goodness of Fit Criteria

\begin{tabular}{cccc}
\hline Goodness of fit index & Cut-off Value & Model Results & Info \\
\hline Chi_square & Expected small & $234,718<(0,05: 34$ & Marginal \\
Probability & $\geq 0,05$ & $=48.6023)$ & Marginal \\
CMIN/DF & $\leq 2,00$ & 0,000 & Marginal \\
RMSEA & $\leq 0,08$ & 6,903 & Marginal \\
GFI & $\geq 0,90$ & 0,136 & Good \\
AGFI & $\geq 0,90$ & 0,879 & Good \\
TLI & $\geq 0,94$ & 0,805 & Good \\
CFI & $\geq 0,94$ & 0,838 & Good \\
\hline
\end{tabular}

As shown in table 4, it can be seen that by including five indicators that have measured the variable/construct of Organizational Citizenship Behavior (Y) and five indicators that measure ASN performance in the analysis model, it has been able to show the existence of a model that is reasonably fit or marginal between the data and the model. The eight index values evidence this, and the marginal ones are chi-square, probability, CMIN/DF, RMSEA, and TLI. Meanwhile, GFI, AGFI, and CFI have complied with the established standards. Based on this, the above model can show a relatively good level of acceptance, so it can be concluded that the model is acceptable and allows for further analysis.

Table 5. Loading Factor Measurement Variable

\begin{tabular}{ccccc}
\hline Indicator Variables & Loading Factor $(\boldsymbol{\lambda})$ & Critical Ratio & Probability & Info \\
\hline Y1.1 & 0,772 & 17,089 & 0,000 & Significant \\
Y1.2 & 0,886 & FIX & 0,000 & Significant \\
Y1.3 & 0,704 & 13,272 & 0,000 & Significant \\
Y1.4 & 0,758 & 14,782 & 0,000 & Significant \\
Y1.5 & 0,607 & 11,258 & 0,000 & Significant \\
Z1.1 & 0,903 & FIX & 0,000 & Significant \\
Z1.2 & 0,918 & 22,882 & 0,000 & Significant \\
Z1.3 & 0,551 & 10,718 & 0,000 & Significant \\
Z1.4 & 0,504 & 9,354 & 0,000 & Significant \\
Z1.5 & 0,481 & 8,967 & 0,000 & Significant \\
\hline
\end{tabular}

Table 5 shows that the ten indicators show positive and significant values; so that all indicators can be included in the next test. Furthermore, the initial Structural Equation Modeling (SEM) analysis was carried out, which is presented in Figure 4. 


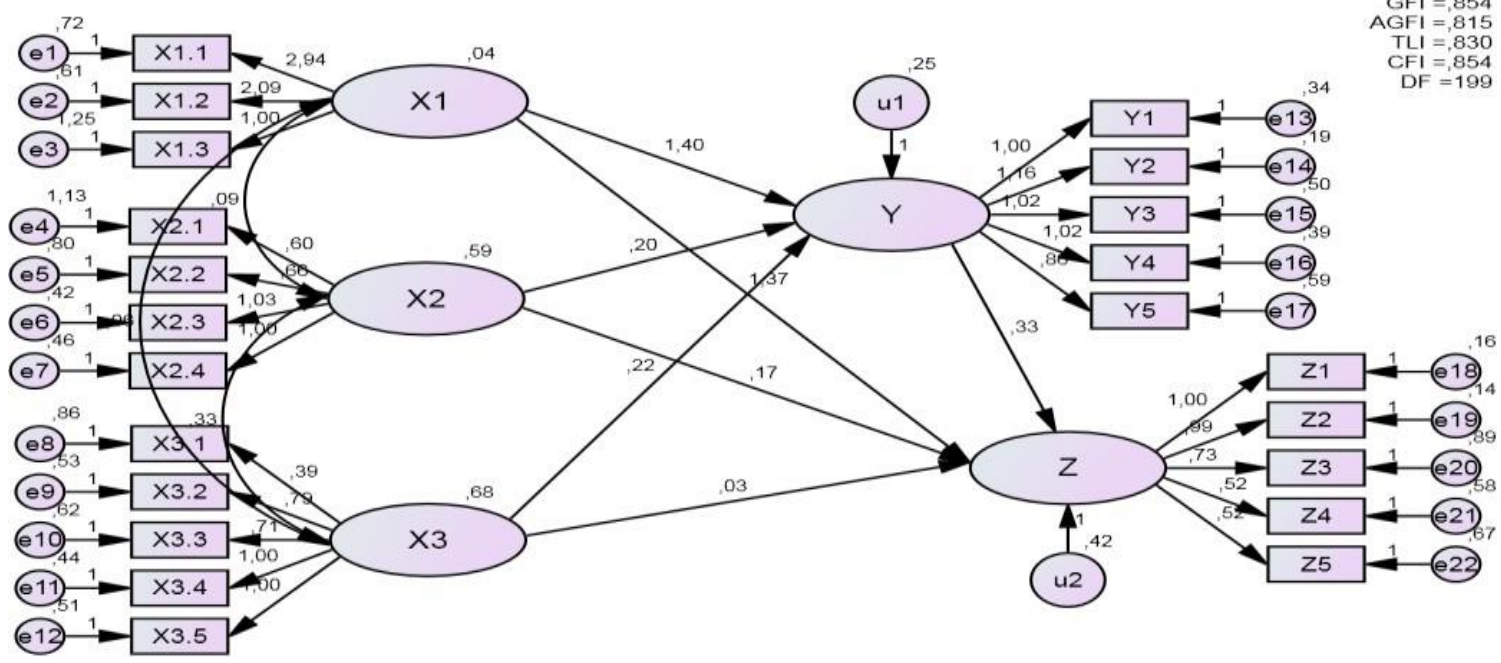

Figure 3. Structural Equation Modeling Asn Performance (Modification 1)

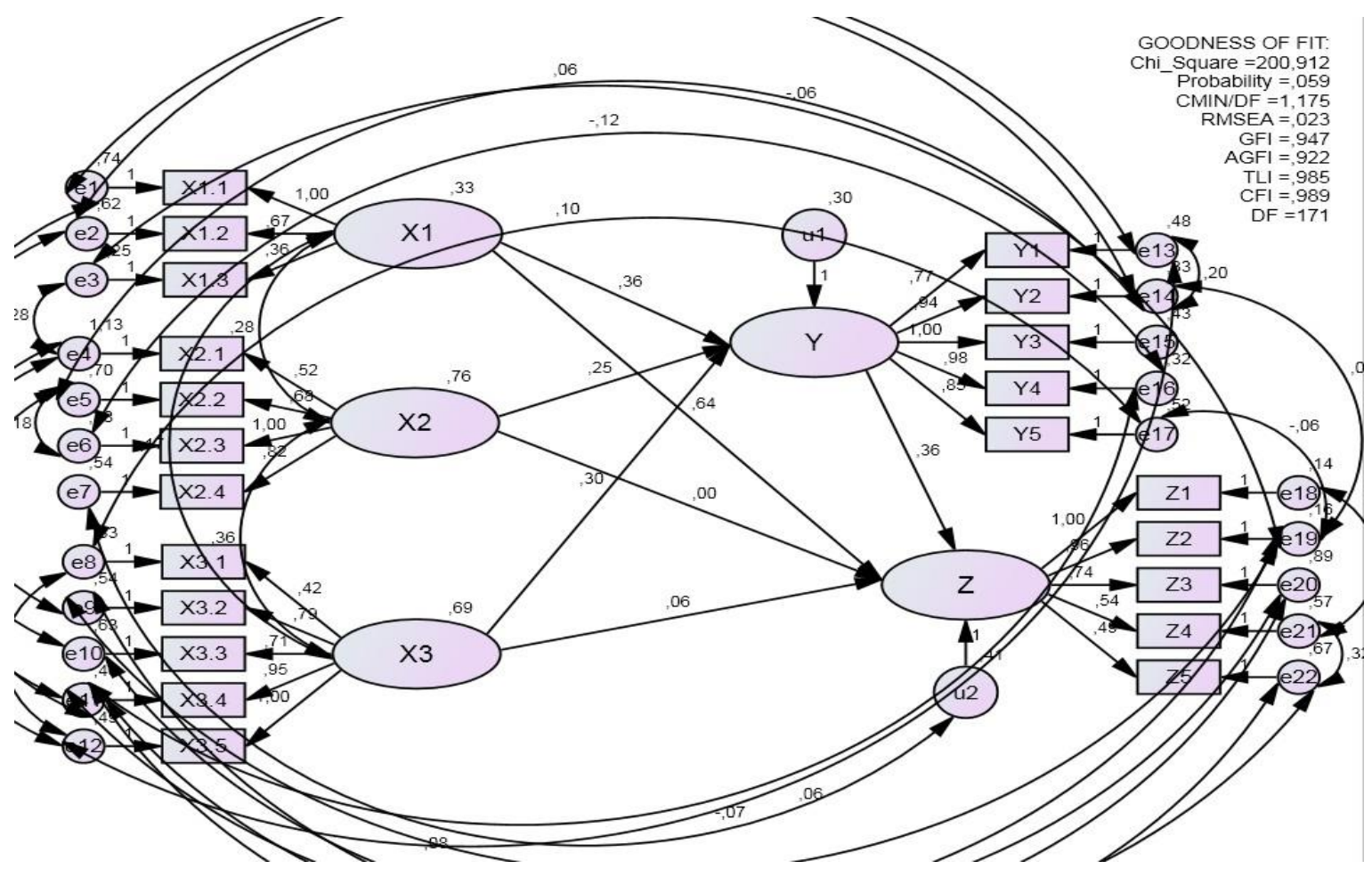

Figure 4. SEM final model measurement

Figure 3 shows that of the eight models of the goodness of fit indices criteria, it appears that there are still some that do not meet the criteria, but seeing the number of indicators is relatively tiny, namely 22 indicators $(12<\mathrm{m}<30)$, it is necessary to prove 
whether there is a match between the model and the data through fulfillment goodness of fit indices criteria so that modification of the model is carried out by conducting correlations between error indicators by the instructions from modification indices with the condition that modifications are carried out without changing the meaning of the relationship between variables. The final results in line with the final model obtained are as follows:

Table 7. Evaluation of the criteria for Goodness of Fit Indices Overall Early Stage Model

\begin{tabular}{llcc}
\hline Goodness of fit index & \multicolumn{1}{c}{ Cut-off Value } & Model REsult & Info \\
\hline \multicolumn{1}{c}{ Chi_square } & Expected small & $598,992<(0,05: 199$ & Marginal \\
Probability & & $=232.911)$ & \\
CMIN/DF & $\geq 0,05$ & 0,000 & Marginal \\
RMSEA & $\leq 2,00$ & 3,010 & Marginal \\
GFI & $\leq 0,08$ & 0,079 & Marginal \\
AGFI & $\geq 0,90$ & 0,854 & Marginal \\
TLI & $\geq 0,90$ & 0,815 & Marginal \\
CFI & $\geq 0,94$ & 0,830 & Marginal \\
\hline
\end{tabular}

Table 8. Evaluation of Criteria for Goodness of Fit Indices Structural Model (Final Analysis Model).

\begin{tabular}{llrl}
\hline $\begin{array}{l}\text { Goodness of fit } \\
\text { index }\end{array}$ & Cut-off Value & Model Result & Info \\
\hline Chi_square & Expected small & $\begin{array}{l}\text { 200,912 }(0,05: 171 \\
\text { =202.512) }\end{array}$ & Good \\
& $\geq 0,05$ & 0,059 & Good \\
Probability & $\leq 2,00$ & 1,175 & Good \\
CMIN/DF & $\leq 0,08$ & 0,023 & Good \\
RMSEA & $\geq 0,90$ & 0,947 & Good \\
GFI & $\geq 0,90$ & 0,922 & Good \\
AGFI & $\geq 0,94$ & 0,985 & Good \\
TLI & $\geq 0,94$ & 0,989 & Good \\
CFI & & & \\
\hline
\end{tabular}

The model evaluation shows that the eight goodness of fit indices criteria all meet the criteria. The overall model can be said to be by the data and can be analyzed further. It is said to be by the data and can be analyzed further. Table 9 is a hypothesis testing by looking at the value. If the p-value is less than 0.05 , then the influence between the variables is significant. The test results are presented in the following table 9: 
Table 9. Direct Effects and Indirect Effects Between Variables

\begin{tabular}{|c|c|c|c|c|c|c|c|c|}
\hline Hip & Independent & $\begin{array}{l}\text { Variable } \\
\text { Intervining }\end{array}$ & Dependent & Direct & Indirect & Total & $\begin{array}{c}\text { P- } \\
\text { Value }\end{array}$ & Info \\
\hline 1 & $\begin{array}{l}\text { HR Development } \\
\text { (X1) }\end{array}$ & - & $\begin{array}{l}\text { OCB } \\
(\mathrm{Y})\end{array}$ & 0,270 & - & 0,270 & 0,040 & $\begin{array}{c}(+) \\
\text { Significant }\end{array}$ \\
\hline 2 & $\begin{array}{l}\text { Competence } \\
\text { (X2) }\end{array}$ & - & $\begin{array}{l}\text { OCB } \\
(Y)\end{array}$ & 0,282 & - & 0,282 & 0,006 & $\begin{array}{c}(+) \\
\text { Significant }\end{array}$ \\
\hline 3 & $\begin{array}{c}\text { Motivation } \\
\text { (X3) }\end{array}$ & - & $\begin{array}{l}\mathrm{OCB} \\
(\mathrm{Y})\end{array}$ & 0,328 & - & 0,328 & 0,000 & $\begin{array}{c}(+) \\
\text { Significant }\end{array}$ \\
\hline 4 & $\begin{array}{l}\text { HR Development } \\
\text { (X1) }\end{array}$ & - & $\begin{array}{c}\text { Permor } \\
\text { mance } \\
\text { ASN } \\
(\mathrm{Z})\end{array}$ & 0,420 & - & 0,420 & 0,010 & $\begin{array}{c}(+) \\
\text { Significant }\end{array}$ \\
\hline 5 & $\begin{array}{l}\text { Competence } \\
\text { (X2) }\end{array}$ & - & $\begin{array}{c}\text { Permor } \\
\text { mance } \\
\text { ASN } \\
(\mathrm{Z})\end{array}$ & 0,002 & - & 0,002 & 0,981 & $\begin{array}{l}\text { (+)Not } \\
\text { significant }\end{array}$ \\
\hline 6 & $\begin{array}{l}\text { Motivatio } \\
\text { n (X3) }\end{array}$ & - & $\begin{array}{c}\text { Permor } \\
\text { mance } \\
\text { ASN } \\
(\mathrm{Z})\end{array}$ & 0,055 & - & 0,055 & 0,483 & $\begin{array}{l}(+) \text { Not } \\
\text { significant }\end{array}$ \\
\hline 7 & $\begin{array}{l}\text { OCB } \\
(\mathrm{Y})\end{array}$ & - & $\begin{array}{c}\text { Permor } \\
\text { mance } \\
\text { ASN } \\
(\mathrm{Z})\end{array}$ & 0,316 & - & 0,316 & 0,002 & $\begin{array}{c}(+) \\
\text { Significant }\end{array}$ \\
\hline 8 & $\begin{array}{l}\text { HR Development } \\
\text { (X1) }\end{array}$ & OCB (Y) & $\begin{array}{c}\text { Permor } \\
\text { mance } \\
\text { ASN } \\
(\mathrm{Z})\end{array}$ & 0,270 & 0,085 & 0,355 & 0.085 & $\begin{array}{l}\text { (+)Not } \\
\text { significant }\end{array}$ \\
\hline 9 & Competence (X2) & OCB (Y) & $\begin{array}{c}\text { Permor } \\
\text { mance } \\
\text { ASN } \\
(\mathrm{Z})\end{array}$ & 0,282 & 0,089 & 0,380 & 0.038 & $\begin{array}{c}(+) \\
\text { Significant }\end{array}$ \\
\hline 10 & Motivation (X3) & OCB (Y) & $\begin{array}{c}\text { Permor } \\
\text { mance } \\
\text { ASN } \\
(\mathrm{Z})\end{array}$ & 0,328 & 0,103 & 0,440 & 0.010 & $\begin{array}{c}\quad(+) \\
\text { Significant }\end{array}$ \\
\hline
\end{tabular}

Direct effect means a direct positive/negative influence between variables. In contrast, indirect effect means an indirect positive/negative influence between variables, and the total effect is the accumulation of the direct and indirect influence. Of the overall models carried out, there are direct effects (five paths that have a positive and significant effect and two paths that are positive and insignificant), while for indirect effects, there are (one path that is positive and insignificant and two paths that are positive and significant).

\section{DISCUSSION}

The results of testing the first hypothesis show that HR development affects Organizational Citizenship Behavior. These results illustrate that if human resource development is carried out correctly, the OCB of ASN at the Regional Apparatus 
Organization (OPD) for the Scope of the Regional Government of Sinjai Regency, South Sulawesi Province, is also getting better. From the respondents' answers, the indicator of the need for a standard of employees who will take part in education and training is the indicator that contributes the most to the development of human resources in the Regional Government of Sinjai Regency, South Sulawesi Province. (Smith, 2000) explains that training is a planned process to change attitudes, behavior, knowledge and skills through learning experiences to achieve effective performance. According to (Sinambela et al., 2021) that HR planning is the process of determining labor needs and efforts to meet these needs so that their implementation is integrated with organizational planning. A training carried out aims to improve the skills of employees. The results of this test indicate that employee development in an organization is very important to improve OCB attitudes in employees. The results of this study also support the statement put forward by (Griffin and Griffin, 2001) which states that development and empowerment as well as organizational commitment have a significant effect on ASN OCB. The development of ASN HR and OCB at the Regional Government OPD of the Sinjai Regency, South Sulawesi Province seems to have been implemented well. This can be seen based on the description of respondents' answers in following organizational changes by participating in activities to improve abilities, knowledge, and skills. They take advantage of the time available to develop themselves in terms of improving their skills and knowledge.

The results of testing the second hypothesis show that competence has a positive and significant influence on Organizational Citizenship Behavior. It means that if the competence of ASN is implemented well, then the OCB in ASN Regional Apparatus Organizations (OPD) within the scope of the Regional Government of Sinjai Regency, South Sulawesi Province, will also be better. Competence is another essential factor that needs to be considered if the organization wants its employees to behave OCB. Competence is an ability based on skills and knowledge supported by work attitudes and refers to the work requirements set. (Mangkunegara, 2013) states that human resource competencies need to be possessed for those who will have a career in human resources mature personality with good emotional intelligence. Competence is the ability and willingness to perform a task effectively and efficiently to achieve company goals. One of the problems related to competence can be seen from the placement of employees, where out of all 320 permanent employees in ASN Regional Apparatus Organizations (OPD) the Scope of the Regional Government of Sinjai Regency, South Sulawesi Province, there is still a mismatch of placement when viewed from the level of education, namely, there are several employees whose placement not by the educational background of the employee so that there is a gap between duties and responsibilities because there is no match between the level of education and the position or position he holds. The statistical test results obtained have relevance and conformity with the research results (Hall et al., 2009; Reza et al., 2018; and Jo and Joo, 2011) showing that competence partially has a significant effect on organizational citizenship behavior.

The results of testing the third hypothesis indicate that motivation has a positive and significant effect on Organizational Citizenship Behavior. These results indicate that if the motivation of ASN is carried out well, the OCB in ASN of Regional Apparatus Organizations (OPD) within the Scope of the Regional Government of Sinjai Regency, South Sulawesi Province, is also getting better. (George and Jones, 2005) explained that the element of work motivation is divided into three parts: the direction of behavior, the level 
of effort, and persistence. The work motivation given by ASN to Regional Apparatus Organizations (OPD) within the scope of the Regional Government of Sinjai Regency, South Sulawesi Province to ASN can foster an excellent direction of employee behavior. The direction of the behavior of ASN Regional Apparatus Organizations (OPD) The scope of the Regional Government of Sinjai Regency, South Sulawesi Province supports the development and goals of the company so that employees establish good relations with their colleagues, obey the work rules set by the company, never skip work or are absent without attending notification, and in working everyday employees are always present on time. On the other hand, the behavior direction of employees who have low work motivation hinders the smooth running of the company in achieving its goals. The level of effort or effort talks about how hard a person tries to work according to the chosen behavior. The level of ASN's effort in Regional Apparatus Organizations (OPD) The Scope of the Sinjai Regency Government of South Sulawesi Province in working can be shown through initiatives to improve their work results that are not good, always work carefully, and concentrate on work. The level of persistence refers to the motivation of ASN when faced with a problem, obstacle, or obstacle in working, how hard an employee continues to try to carry out the chosen behavior as implemented by the Regional Apparatus Organization (OPD) for the Scope of the Sinjai Regency Government, South Sulawesi Province, always tries to complete work according to organizational standards, always tries not to make mistakes at work, makes reprimands from leaders as motivation, and continues to work as usual despite the lousy weather, in this case, an exception is made if the health problems experienced by employees include serious illnesses that can cause a person to be unable to work. Organizational Citizenship Behavior (OCB), according to (Organ, 2018) has five dimensions: altruism, conscientiousness, civic virtue, courtesy, and sportsmanship at PT. Pelabuhan Indonesia III (Persero) Tanjung Perak Surabaya Branch, The emergence of organizational citizenship behavior (OCB), can be seen in the core values that are applied. These values are customer focus, care, and integrity.

The Effect of Motivation on Organizational Citizenship Behavior (OCB). The results of this study indicate that work motivation factors influence OCB. That is, when employees do work outside of their job description or work voluntarily beyond working hours, never disappear during the day at work, come to the office early if needed and spend time working, and are based on motivation or the need to get recognition or the need to excel. However, this is solely to carry out tasks according to the procedures and responsibilities set by the company because the industry in this company has a high level of risk. It requires readiness, discipline, accuracy, and timeliness in work. (Reza et al., 2018) describes several factors that influence OCB: organizational culture and climate, personality and mood, perceptions of organizational support, perceptions of the quality of relationships/interactions between superiors and subordinates, years of service, and gender. The culture and work climate of oil and gas industry companies certainly has a strict procedural level. Employees need procedural permission first, even if they help their friends carry out their duties.

(Mushtaq et al., 2014) motivation is a collection of energetic forces that coordinate inside and outside a worker, which drives work effort in determining direction, intensity, and persistence. Work motivation is a collection of psychological processes that cause movement, direction, and persistence of voluntary attitudes that lead to goals. Work motivation can be interpreted as encouragement. (Sinambela et al., 2021) there are three elements in work motivation: direction of behavior, level of effort, and level of persistence. 
Behavioral direction refers to employees' behavior from the many potential behaviors they can exhibit. The level of effort is not enough for the organization to motivate its employees to exhibit behaviors to function for the company. The organization must also motivate them to work hard in these behaviors. Level of persistence: when faced with obstacles, dead ends, and stone walls, one's ability to keep trying to demonstrate well-chosen behavior.

After testing the direct influence between HR development (X2) on employee performance $(\mathrm{Y})$, the results obtained indicate that the two variables tested have a significant direct effect. This variable has a positive effect. Suppose the development is carried out in earnest. In that case, the performance of ASN in Regional Apparatus Organizations (OPD) within the Scope of the Regional Government of Sinjai Regency, South Sulawesi Province, will also be good. So this proves that there is a direct influence between HR development variables (X2) on employee performance (Y). According to (Tai et al., 2012) (Kurniawan, 2012), career development opportunities for ASN employees are relative, encouraging increased performance as indicated by the completion of the task volume expected by the company. It is like what happened to the Regional Apparatus Organization (OPD) for the Scope of the Regional Government of Sinjai Regency, South Sulawesi Province. ASN employees feel that in providing opportunities for self-development and career development, the agency is very fair. For example, they feel that they can explore their new abilities well and improve their career in improving their abilities. In order to increase class and rank, all employees are well informed, even given counseling by their seniors on what is needed to pass the administration. In the promotion of class, all employees are entitled to follow. This promotion is held every 4 years. In addition, promotions are also held.

After testing the direct effect of competence on ASN performance, the results obtained indicate that the two variables tested have a direct effect which is positive and insignificant, meaning that good competence from employees will increase confidence in completing tasks on time and smoothly so that it can improve ASN performance at ASN Regional Apparatus Organizations (OPD) within the scope of the Regional Government of Sinjai Regency, South Sulawesi Province.

By the theory, achievement and acting competencies can predict or cause good performance (Spencer and Spencer, 1993). Competence of achievement and action is the spirit of achievement by which individuals act beyond what is required or required by work and influence, such as taking the initiative in pursuing personal and organizational goals and implementing ideas, and solving problems that ultimately lead to increased performance (Spencer and Spencer; 1993, Grant and Ashford, 2008). According to (Spencer, 1993) the relationship between employee competence and performance is very close and significant. The relevance exists and is solid and accurate. Even if employees want to improve their performance, they should have competencies by their job duties. Competence can cause or be used to predict a person's performance, meaning that if he has high competence, he will also have high performance.

Another study was conducted by (Darwinanti, 2008), which examined the influence of Human Resource Competence on Employee Performance (Study at PT Perkebunan Nusantara III Deli Serdang-2 Sei Karang Galang). The results obtained indicate that the competence of human resources consisting of knowledge, behavior or attitudes, skills, and work experience simultaneously affects employee performance. 
Direct Effect of Motivation on ASN Performance. After testing the direct effect of motivation on ASN performance, the results obtained indicate that the two variables tested have a direct effect which is positive and not significant, meaning that if the motivation of ASN is carried out well but has not been able to maximize the performance of the ASN of Regional Apparatus Organizations (OPD) within the Scope of the Regional Government of Sinjai Regency, South Sulawesi Province. According to M. (Manullang, 2001) motivation is the work done by a manager to provide inspiration, enthusiasm, and encouragement to others. In this case, the employee to take action, giving this encouragement aims to activate employees so that they are enthusiastic and can achieve the desired results. Employees are one of the keys to the company to develop itself. The existence of employees is necessary to build maximum performance so that the company's goals are achieved. Maximum performance can be measured based on high ability. The higher the level of workability indicates that the company's performance is getting better. Therefore, if employees are cared for properly, of course, a company will progress and develop. The performance itself can be defined as the number of results achieved by an employee in a certain period. In general, performance implies a comparison between the results achieved and the overall resources used. According to (Warsito, 2008), individual performance is influenced by motivation, ability, and work environment factors.

Based on the above understanding, it can be concluded that one of the efforts to improve employee performance is to provide work motivation to employees. According to (Manullang, 2001) motivation is the work done by a manager to provide inspiration, enthusiasm, and encouragement to others. In this case, employees take action. Giving this encouragement aims to activate employees so that they are enthusiastic and can achieve the desired results. The need for self-confidence, the need for autonomy, the need for autonomy, the need for competence, the need for recognition, and the need for status. Meanwhile, existence needs are provided in the form of clothing needs in the form of work clothes/uniforms, housing needs in official housing, food needs, retirement insurance needs, accident insurance coverage, and the need to be free from fear of being displaced from work. In contrast, growth needs are given in the form of self-potential needs and self-development needs.

Theoretically, work motivation can be implemented through existence needs, relationship needs, growth needs (Warsito, 2008). Based on the research conducted, the policy provides work motivation in the ASN of Regional Apparatus Organizations (OPD) within the Scope of the Regional Government of Sinjai Regency, South Sulawesi Province, deemed appropriate to improve employee performance. The provision of work motivation is directed at meeting the physical and mental needs of employees and their families so that they will be able to create a calm, work enthusiasm, dedication, discipline, and employee loyalty towards the company so that labor turnover is relatively low. Understanding the role of work motivation in improving employee performance leads to an understanding of how important work motivation is as part of the company's efforts to improve employee welfare which ends in improving performance. High performance in each aspect according to the employee's duties and responsibilities will create a good synergy within the company. It will make the company able to compete and develop for the betterment of the company itself.

Direct Effect of Organizational Citizenship Behavior (Z) on ASN Performance. After testing the direct influence between Organizational Citizenship Behavior (Y1) on ASN 
performance (Y2), the results obtained indicate that the two variables tested have a significant direct effect. This variable has a positive effect. Suppose OCB is carried out seriously by ASN. In that case, The performance of the Regional Apparatus Organization (OPD) within the scope of the Sinjai Regency Government, South Sulawesi Province will also be good. So this proves that there is a direct influence between the OCB variable (Y1) on the performance of ASN (Y2). The results of this study also support the results of research by Nufus (2011) which states that the variable Organizational Citizenship Behavior (Z) has a significant effect on the employees of the Kediri Regency Tourism Office. Also, (Rachmawati and Dewi's, 2012) research results on the relationship between organizational citizenship behavior (OCB) performance in public elementary school teachers after the teacher certification program have a significant relationship. The results of Nufus' research (2011), increasing the conscientiousness dimension will improve employee performance. Behavior to arrive early, come to work on time, come immediately when needed, and not take excess time. It is very much by the reality in the Regional Apparatus Organization (OPD) within the Scope of the Regional Government of Sinjai Regency, South Sulawesi Province. Where there are no employees who arrive late, this can be seen when attending the morning at 7.00 they have gathered neatly on the page of the Kediri Regency Culture and Tourism Office. There is not a single employee who came late or did not attend the morning apple. In addition, they also go home on time at 15.00.

None of them went home early unless there were still official matters in the field or other services. It is also supported by the presence of a fingerprint that is used when coming home from work. With employees who have a high OCB attitude, it means that employees are more loyal to this agency. High loyalty will also lead to good employee performance in an agency. As seen in the Regional Apparatus Organization (OPD) for the Scope of the Regional Government of Sinjai Regency, South Sulawesi Province, employees already feel they have this agency, can keep agency secrets, and prioritize good cooperation. It can be seen when they help their co-workers in need, coordinate well, do not look for problems with co-workers, and often share essential information they know.

Indirect Effect of HR Development (X2) on ASN Performance (Y2) through Organizational Citizenship Behavior (Y1). The study results have proven that the variable of HR development has a positive and significant effect on the performance of ASN through Organizational Citizenship Behavior. It implies that the human resources development variable indicators are the total number of human resources, the number of human resources needed, education and training, and determining the human resources in the future. These variables can contribute positively to the performance of ASN in the local government of Sinjai Regency, South Sulawesi Province. . Human resource development to ensure that qualified ASN employees achieve organizational goals in improving ASN performance, the above objectives can be achieved by ensuring that everyone in the organization has the knowledge and expertise to achieve the level of ability required to carry out their work effectively. (Sinambela, 2016). Reliable human capital can be obtained from the level of education and training they have done. If an organization has a Human Resources (HR) professional, quality, commitment, and integrity that both confirm the organization could thrive.

Training Local Governments Sinjai, South Sulawesi Province, by determining the type of education and training tailored to the needs of program planning, is an activity to 
improve performance and performance in the future. Training is a process of systematically changing employee behavior to achieve organizational goals. Training has a current orientation and helps employees achieve specific skills and abilities to succeed in carrying out their work (Veithzal, 2013). It is in line with Dessler's opinion in (Sinambela, 2016), that new and old employees need the training to add skills needed by employees and needed for promotion in certain positions. In carrying out its duties and functions and realizing the vision and mission of the Government of Sinjai Regency, South Sulawesi Province, the best Human Resources (HR) are needed by the number of ASN, which totals approximately 320 employees main focus, and always cooperative in realizing the vision and mission of the Government of Sinjai Regency, South Sulawesi Province. Currently, the authors observe employees' work behavior who still think for their respective fields and work only to the extent of the tasks assigned to these employees. Employees still do not think about working broadly for the organization's benefit and have not been able to innovate for better organizational development. It takes work behavior that goes beyond their role and the ability to innovate.

Work behavior that exceeds the demands of the role in the organization and can lead to the achievement of excellent performance is known as organizational citizenship behavior or OCB (Aldag and Reschke, 1997) (Darto, 2014). This OCB involves several behaviors such as helping behavior, obeying the rules at work, and being willing to do extra tasks. OCB is very much needed in the current era of bureaucratic reform. This OCB behavior is not forced on employees but a choice taken by employees in advancing their organization's performance. Employees who have OCB behavior will be willing to work beyond their responsibilities to better the organization. This research is consistent with research that has been conducted by (Fiqih Hidayah et al., 2014; Ling Tai et al., 2012; Suhardi, 2019; Yoga et al., 2016).

Indirect Effect of Competence on ASN Performance through Organizational Citizenship Behavior $(\mathbf{Z})$. Based on the path analysis, it shows that there is an indirect influence between the competence variable (X3) on the ASN performance variable (Y2) through the Organizational Citizenship Behavior (Y1) variable in the Regional Apparatus Organization (OPD) within the scope of the Regional Government of Sinjai Regency, South Sulawesi Province. The higher the competence, the higher the performance of the ASN. On the other hand, if HR development is lower, employee performance will be lower. Competence is another essential factor that needs to be considered if the organization wants its employees to behave OCB. (Sutrisno, 2014) states that competence is an ability based on skills and knowledge supported by work attitudes and refers to the work requirements set. (Mangkunegara, 2013) states that human resource competencies need to be possessed for those with a career in human resources and a mature personality with good emotional intelligence. (Hutapea and Thoha, 2008) explain that competence is the ability and willingness to perform a task effectively and efficiently to achieve company goals.

The results of this study reveal that employees with all their characteristics and potential must be seen as an integrated and synergized unit to create an effective performance. The four research variables indicators (knowledge, skills, self-concept and values, personal characteristics) theoretically should be a link that interacts, complements, and supports each other. These four indicators must show a sufficient and unidirectional relationship. Thus, the results of the path test show that all indicators have a good effect and 
are in the same direction as the other variables. It shows that employees have a fully integrated characteristic foundation capable of optimizing their potential. Thus, this is considered sufficient and fulfills the minimum requirements to create an effective performance. As revealed by the SMR team (specialist Management Resources) (Palan, 2007), knowledge, skills, self-concept and values, personal characteristics possessed by a person are considered sufficient, minimally for effective performance.

Indirect Effect of Motivation on ASN Performance through Organizational Citizenship Behavior (Z). Based on path analysis, it shows that there is an indirect influence between motivational variables (X3) on ASN performance variables (Y2) through Organizational Citizenship Behavior (Y1) variables in Regional Apparatus Organizations (OPD) within the scope of the Regional Government of Sinjai Regency, South Sulawesi Province. The higher the motivation, the higher the performance of the ASN. On the other hand, if HR development is lower, employee performance will be lower. The study results indicate that the motivation carried out by the Regional Apparatus Organization (OPD) within the scope of the Regional Government of Sinjai Regency, South Sulawesi Province, is by the motivation theory proposed by (Robbins and Judge, 2008). Motivation is a process that describes the intensity, direction, and persistence of an individual to achieve his goals. In this context, motivation focuses on organizational goals to reflect the interest in workrelated behavior.

(Harwiki, 2013) consider motivation a series of attitudes and values that influence individuals to achieve specific things according to individual goals. (Nur et al., 2015) revealed that motivation is triggered by three factors, (eg, the possibility to develop, type of work, and whether they can feel proud to be part of the company). (Greenberg and Baron, 2008) define OCB as a voluntary action beyond formal work requirements. A form of informal behavior in which a person exceeds formal expectations in contributing to the wellbeing of the organization and the people in it. (Robbins and Judge, 2008) describe OCB as optional behavior that is not part of an employee's formal work obligations but supports the effective functioning of the organization.

The results of this study are in line with the results of research conducted by (Griffin and Griffin, 2001) which states that organizational citizenship behavior (OCB) can mediate the effect of work motivation on team member performance fully. Work motivation affects performance has also been proven from the results of research from (Eka, 2015) which concludes that there is an effect of work motivation on performance. The results of this study are supported by (Ek and Mukuru, 2013). However, there are still differences from a study conducted by Riana, (2015). The results of his research do not prove the influence of motivation on performance. Research conducted by (Yeh et al., 2012; Memari et al., 2013) the results of his study prove that organizational commitment is significantly positive on employee performance. However, in contrast to the results of research from (Subejo et al., 2013), his research did not find a significant effect of organizational commitment on employee performance.

\section{CONCLUSION}

Based on the results of research and discussions that have been carried out, we found that the results of the HR development test had a positive and significant effect on 
Organizational Citizenship Behavior and ASN performance. Competence directly has a positive and significant effect on $\mathrm{OCB}$, and competence has a positive and insignificant effect on ASN performance. The value of motivation directly has a positive and significant effect on Organizational Citizenship Behavior and indirectly has an insignificant effect on ASN performance. From the results of the tests carried out in this study, we conclude that this shows that if HR continues to be improved, OCB and ASN performance will also increase.

Directly, Organizational Citizenship Behavior impacts employees so that employees work optimally so that ASN performance increases. Indirectly, the development of human resources has not been maximized to improve the performance of ASN, which Organizational Citizenship Behavior mediates. Indirectly, competence on ASN performance through Organizational Citizenship Behavior has a positive and significant influence. It means that Organizational Citizenship Behavior as an intervening variable can mediate the competence variable on ASN performance. Indirectly, motivation on ASN performance through Organizational Citizenship Behavior has a positive and significant influence. The variable Organizational Citizenship Behavior as an intervening variable can mediate the variable Organizational Citizenship Behavior and ASN performance. The research time is relatively short, namely for four months, so the sample's representativeness is still not optimal. Research findings are limited and only related to the variables used in the study. The results of this study suggest that the competencies possessed by employees need special attention so that it is recommended to the Regional Apparatus Organizations (OPD) for the Scope of the Regional Government of Sinjai Regency, South Sulawesi Province so that employee competencies can be developed by their respective fields in order to work to improve ASN performance. Directly, the motivation of employees has been carried out well but has not been able to improve the performance of ASN, so it is recommended that the Regional Apparatus Organization (OPD) for the Scope of the Regional Government of Sinjai Regency, South Sulawesi Province, in order to give special attention to employees.

\section{REFERENCES}

Abrianto, H., and Srimulyani, V. A. (2021). Peningkatan Employee Engagement melalui Budaya Organisasi dan Kepemimpinan Kredibel. Jurnal Riset Manajemen Dan Akuntansi, 9(01).

Boyle, B. A., and Dwyer, F. R. (1995). Power, bureaucracy, influence, and performance: Their relationships in industrial distribution channels. Journal of Business Research, 32(3), 189-200.

Buana, I., dan Wirawati, N. G. P. (2018). Pengaruh kualitas sistem informasi, kualitas informasi, dan perceived usefulness pada kepuasan pengguna sistem informasi akuntansi. E-Jurnal Akuntansi Universitas Udayana, 22(1), 683-713.

Chiaburu, D. S., Chakrabarty, S., Wang, J., and Li, N. (2015). Organizational support and citizenship behaviors: A comparative cross-cultural meta-analysis. Management International Review, 55(5), 707-736.

De Waal, A. A. (2010). Achieving high performance in the public sector: what needs to be done? Public Performance \& Management Review, 34(1), 81-103.

Ghozali, I. (2005). Uji Asumsi Klasik. Jurnal Akuntansi, 3. 
Ginanti, M. G., Muis, M., dan Pono, M. (2018). Analisis Pengaruh Kompetensi, Pelatihan Dan Kompensasi Terhadap Kinerja Karyawan Dengan Kepuasan Kerja Sebagai Variabel Intervening Pada Tim Tanggap Darurat Fire And Emergency Services Di Wilayah Kerja Tambang Pt Vale Ind Tbk. Hasanuddin Journal of Applied Business and Entrepreneurship, 1(4), 65-72.

Griffin, M., and Griffin, W. (2001). organizational Behavior People and Organization. Arizona state University, Boston New york: Managing Hokghton Mifflin Company.

Hall, A. T., Zinko, R., Perryman, A. A., and Ferris, G. R. (2009). Organizational citizenship behavior and reputation: Mediators in the relationships between accountability and job performance and satisfaction. Journal of Leadership \& Organizational Studies, 15(4), 381-392.

Hartog, M., and Winstanley, D. (2002). Ethics and human resource management: Professional development and practice. Business \& Professional Ethics Journal, 21(2), 3-9.

Harwiki, W. (2013). Influence of servant leadership to motivation, organization culture, organizational citizenship behavior (OCB), and employee's performance in outstanding cooperatives East Java Province, Indonesia. IOSR Journal of Business and Management (IOSR-JBM), 8(5), 50-58.

Hidayah Tunggal Wiranti, F. (n.d.). Pengaruh Kepemimpinan, Motivasi Kerja dan Kepuasan Kerja melalui Organizational Citizenship Behavior (OCB) terhadap Kinerja Guru Sekolah Dasar Negeri Kecamatan Mayang Kabupaten Jember.

House, R. J., and Wigdor, L. A. (1967). Herzberg's dual- factor theory of job satisfaction and motivation: A review of the evidence and a criticism. Personnel Psychology, 20(4), 369-390.

Jo, S. J., and Joo, B.-K. (2011). Knowledge sharing: The influences of learning organization culture, organizational commitment, and organizational citizenship behaviors. Journal of Leadership \& Organizational Studies, 18(3), 353-364.

Luthan, E., Rizki, S. A., dan Edmawati, S. D. (2017). Pengaruh pengungkapan tanggung jawab sosial perusahaan terhadap kinerja keuangan. EKUITAS (Jurnal Ekonomi Dan Keuangan), 1(2), 204-219.

Mangkunegara, A. P. (2013). The development of Human Resources of the company. To Print-12. Bandung: PT. Remaja Rosdakarya.

Mathis, R. L., and Jackson, J. H. (2006). Human resource management: Manajemen sumber daya manusia. Terjemahan Dian Angelia. Jakarta: Salemba Empat.

Morrison, E. W. (1994). Role definitions and organizational citizenship behavior: The importance of the employee's perspective. Academy of Management Journal, 37(6), 1543-1567.

Mushtaq, K., Ahmed, M., and Warraich, S. (2014). A study on job satisfaction, motivation and organizational citizenship behavior. International Journal of Management Sciences and Business Research, 3(11).

Nunnally, J. C., Thistlethwaite, D. L., and Wolfe, S. (1963). Factored scales for measuring characteristics of college environments. Educational and Psychological Measurement, 23(2), 239-248.

Nur, M., Ali, A., Yusuf, Y., and Chamariyah, C. (2015). The influence of transformational and transactional leadership, and also motivation on employee's performance. Manajemen \& Bisnis (MABIS), 14(2), 131-138. 
Nurun Nabi, I. M., and Dip TM, H. A. A. (2017). Impact of motivation on employee performances: a case study of Karmasangsthan bank Limited, Bangladesh. Arabian J Bus Manag Review, 7(293), 2.

Organ, D. W. (2018). Organizational citizenship behavior: Recent trends and developments. Annual Review of Organizational Psychology and Organizational Behavior, 80, 295306.

Pintrich, P. R. (2003). A motivational science perspective on the role of student motivation in learning and teaching contexts. Journal of Educational Psychology, 95(4), 667.

Pradhan, R. K., and Jena, L. K. (2017). Employee performance at workplace: Conceptual model and empirical validation. Business Perspectives and Research, 5(1), 69-85.

Purwanto, A., Purba, J. T., Bernarto, I., and Sijabat, R. (2021). Effect Of Transformational Leadership, Job Satisfaction, And Organizational Commitments On Organizational Citizenship Behavior. Inovbiz: Jurnal Inovasi Bisnis, 9(1), 61-69.

Reza, M., Rofiaty, R., and Djazuli, A. (2018). The influence of situasional leadership, organizational culture and training on employee performance and work motivation of millenial generation at the inspection office of Bri Malang. Wacana Journal of Social and Humanity Studies, 21(2).

Sinambela, S., Naibaho, P., Simanjuntak, E., dan Wijiangkara, G. (2021). Pengaruh Disiplin Kerja, Pelatihan Kerja Dan Motivasi Terhadap Kinerja Karyawan. Jurnal Manajemen Strategi Dan Aplikasi Bisnis, 4(1), 217-240.

Smith, P. J. (2000). Flexible delivery and apprentice training: preferences, problems and challenges. Journal of Vocational Education and Training, 52(3), 483-503.

Sunarsih, N. (2018). Manajemen Sumber Daya Manusia Berbasis Kompetensi: Strategi Meningkatkan Kemampuan Daya Saing Perusahaan. Jurnal Akrab Juara, 3(1), 17 28.

Tai, C.-C. L., Chang, C.-M., Hong, J.-Y., and Chen, L.-C. (2012). Alternative models for the relationship among leadership, organizational citizenship behavior, and performance: a study of new product development teams in Taiwan. Procedia-Social and Behavioral Sciences, 57, 511-517.

Turnipseed, P. H., and Turnipseed, D. L. (2013). Testing the proposed linkage between organizational citizenship behaviours and an innovative organizational climate. Creativity and Innovation Management, 22(2), 209-216. 